usually an oral contraceptive or an intrauterine device. All were perfectly aware that unprotected intercourse could result in pregnancy.

I talked to most of these patients, and two points emerged clearly. Their emotional relationships were unstable and usually not long-lasting; this also applied to most of the married women. All assumed that the State should provide freedom from their unwanted pregnancy and that terminations are but part of the contraceptive armamentarium. This second point was brought home very clearly one Sunday afternoon when a 22-year-old woman appeared on the ward demanding a termination of pregnancy there and then so that she could start a new job on Monday. She was sent away.

I have no prejudices about termination. In many cases I have seen a termination was done because it was necessary and advisable. Yet with all the available family-planning services provided by the State I cannot help feeling sick when perfectly aware but careless women become pregnant and then treat abortion as just another part of the contraceptive services. This abuse of the N.H.S. and this cheap regard for pregnancy and life is disturbing.

Charing Cross Hospital Medical School, I.ondon W'6

\section{Michèle BeACONSFIELd}

\section{RELATIVE EFFECT OF SMOKING AND OTHER VARIABLES ON SIZE OF NEWBORN}

SIR,-Maternal smoking during pregnancy tends to reduce birthweight, ${ }^{1-4}$ but what is the relative importance of maternal smoking and other maternal variables that affect the size of the infant at birth? One approach to this problem is to explore each variable in turn through the product-moment correlation $(r)$; an alternative is to ascertain the excess of low weight, short stature, low income, or moderate to heavy smoking among the mothers of low-birthweight neonates. We have tried both methods (see tables I and II).

TABLE I-CORRELATIONS $(r)$ BETWEEN FOUR MATERNAL VARIABLES AND CHILD'S BIRTHWEIGHT

\begin{tabular}{l|r|r}
\hline \multicolumn{1}{c|}{ Maternal variable } & $\begin{array}{r}8595 \\
\text { Blacks }\end{array}$ & \multicolumn{1}{c}{$\begin{array}{r}10324 \\
\text { Whites }\end{array}$} \\
\hline Pre-pregnancy weight & 0.26 & 0.25 \\
Hetght & 0.16 & 0.18 \\
Per-caput income & -0.02 & -0.09 \\
Smoking* & -0.16 & -0.22 \\
\hline
\end{tabular}

* By number of cigarettes per day. Correlations represent averages of sex-specific correlations.

The correlational approach with four maternal variables shows that cigarette usage ranks slightly behind maternal (prepregnancy) weight but slightly ahead of maternal stature and well ahead of income (table $\mathrm{I}$ ) in a series of 18919 normalterm singletons. ${ }^{5}$ Given the sample sizes (roughly 10000 ) these values of $r$ may be viewed as valid within \pm 0.01 (the $95 \%$ confidence limits).

Using the excess of low-weight, short, low-income, or moderate-to-heavy smoking mothers of low-birthweight infants, cigarette smoking ( $\geqslant 10$ cigarettes per day) is seen to be associated with low birthweights to the largest degree (table II).

The simple correlational approach compares well with more complicated stepwise regressions and is presented here for simplicity. The excess of small-sized, low-income, and moderateto-heavy smoking mothers provides somewhat different rankings since it directs attention to a portion of the birthweight

\footnotetext{
1 (jarn, S M , Shaw, H. A., McCabe, K. D. in Epidemiology of Prematurity, edited by D. M. Reed and F. Stanley). Baltimore (in the press).

Hardy, J. B., Mellıts, E D. Lancet, 1972, ii, 1332

3 Yerushalmy, J. Am. 7. Eprd. 1971, 93, 443.

+ Hicar, J, Brooke, O. G. Lancet, 1977, 1, 1158

Siswander, K. R., Gordon, M The Women and Their Pregnancies; vol. I. Philadelphia, 1972.
Phander, K. R., Gord
}

TABLE II-EXCESS OF FOUR MATERNAL CATEGORIES ASSOCIATED WITH LOW-BIRTHWEIGHT INFANTS *

\begin{tabular}{|c|c|c|c|c|}
\hline \multirow[b]{3}{*}{ Maternal category } & \multicolumn{4}{|c|}{$\%$ in } \\
\hline & \multicolumn{2}{|c|}{$\begin{array}{c}\text { Total } \\
\text { sample }\end{array}$} & \multicolumn{2}{|c|}{$\begin{array}{l}\text { Low- } \\
\text { birthweight } \\
\text { infants }\end{array}$} \\
\hline & Black & White & Black & White \\
\hline $\begin{array}{l}\text { Pre-pregnancy weight } \\
\leqslant 99 \mathrm{lb}(45 \mathrm{~kg})\end{array}$ & $4 \cdot 6$ & 4.6 & $10 \cdot 2$ & 11.6 \\
\hline Stature $\leqslant 59$ in $(150 \mathrm{~cm})$ & $4 \cdot 7$ & $4 \cdot 1$ & $6 \cdot 4$ & $8 \cdot 2$ \\
\hline $\begin{array}{l}\text { Per-caput income } \\
\leqslant \$ 233 / \text { year } \\
\geqslant 10 \text { cigarettes } / \text { day }\end{array}$ & $\begin{array}{r}7 \cdot 7 \\
39 \cdot 1\end{array}$ & $\begin{array}{r}3 \cdot 3 \\
50 \cdot 3\end{array}$ & $\begin{array}{r}8 \cdot 5 \\
56 \cdot 9\end{array}$ & $\begin{array}{r}3 \cdot 5 \\
76 \cdot 1\end{array}$ \\
\hline
\end{tabular}

* $\leqslant 5$ th percentile for sex and race.

distributions and a portion of the size, income, and smoking distributions. It is, however, in accord with similar analyses of short birth-lengths and low, head circumferences in the neonate, and with the incidence of prematurity in the total sample of 49995 liveborn singletons. ${ }^{5}$

Both by the correlational approach and by the excess of maternal categories associated with low birthweight, maternal smoking during pregnancy thus emerges as the most important single preventible determinant of low birthweights. Moreover, the probability of low birthweight is directly proportional to daily cigarette consumption. ${ }^{6}$ Abstention from smoking or reduction in the number of cigarettes smoked would reduce the frequency of low-birthweight.

The data were drawn from the Collaborative Perinatal Project of the National Instutute of Neurological and Communicative Disorders and Stroke ${ }^{5}$ The study was supported by funds from contract no. N01-NS-5-2308.

Center for Human Growth and Development, University of Michigan,

Ann Arbor, Michigan 48109, U S.A.

S. M. GARN

H. A. SHAW

Collaborative Perinatal Project of

National Institute of Neurological

and Communicative Disorders and Stroke,

National Institutes of Health,

Bethesda, Maryland

K. D. MCCABE

\section{NEPHROPTOSIS}

SIR,- de Zeeuw et al. ${ }^{1}$ reported an association between nephroptosis, fibromuscular dysplasia of the renal artery, and hypertension. However, their statement that none of the normotensive females in their series had a renal mobility of over $7.6 \mathrm{~cm}$ together with the suggestion that nephroptosis may, in the long term, lead to fibromuscular dysplasia of the renal artery poses the question-should one operate on every case of nephroptosis at an early stage, even in the absence of troublesome symptoms? This question is important in Greece where nephroptosis seems to be frequent.

In our records we found thirty-four cases of nephroptosis meeting the criteria of de Zeeuw et al. All these patients were females, aged 19-58, and in all the nephroptosis was of the right kidney. Eleven had no evidence (including aortographic evidence) of fibromuscular dysplasia and none had any other disorder or were taking any drug that might have affected blood-pressure. These eleven patients varied in age from 19 to 55 years (mean 41 ). Only three of the eleven patients were hypertensive. In one (aged 47) the blood-pressure returned to normal after nephropexy and is still normal 10 months after operation. The other two hypertensive patients refused surgery.

The notion that there can be an association between neph-

6. Garn, S. M., Shaw, H. A., McCabe, K. D. in Essays in Honor of Olaf Mickelsen (edited by R. Schemmel). Michigan. Agricultural Experiment Station (in the press). 